\title{
ETHOS EM AMBIENTES PERIFÉRICOS: razão e rebeldia no discurso dos Racionais Mc's
}

\author{
E thos in peripheral environments: reason and \\ rebelliousness in Racionais Mc's speech
}

\author{
Cláudio Rodrigues Coração ${ }^{a}$, Luiz Marcos Ferreira Júnior \\ a Mestrando em Comunicação Midiática (UNE SP), Bauru, SP - Brasil, e-mail: claudiocoracao @ ig.com.br \\ b Mestrando em Comunicação Midiática (UNESP), Bauru, SP - Brasil, e-mail: lcacoman@ gmail.com
}

\section{Resumo}

O presente trabalho é proposto com o intuito de apresentar um particular cadinho social presente no Brasil, os espaços de vida nas periferias de grandes cidades brasileiras, a partir da análise atitudinal de conteúdos e do comportamento ético do grupo Racionais Mc's. O que, segundo os autores, parece favorável para compreender como estratos sociais menos favorecidos nas sociedades latino-americanas têm reagido, mesmo sob circunstâncias mais que desafiadoras e restritivas, e construído mecanismos de reação social. Constata-se, ao final, a necessidade de diferenciar-se os ingredientes éticos e valorativos da classe média e do sujeito periférico no cenário midiatizado contemporâneo. 0 narrador nas três canções escolhidas, utilizando-se de um discurso documental, metalinguístico por vezes, com ares cinematográficos, irá verificar os códigos culturais dos desvalidos, "dos de baixo". Alguns blocos temáticos percorrerão as três canções na ânsia de emoldurar as fronteiras tensivas entre o sujeito periférico (o narrador), a descrição do microcosmo e os diálogos multireferenciais com atores externos (o playboy, os policiais etc.): localização do cenário periférico, condição dos atores, mulher, formas de vida, violência, guerra x paz, actantes externos e "revisão de consciência".

Palavras-chave: Mídia; Periferia; Racionais Mc's; E thos; Solidariedade. 


\begin{abstract}
This work is proposed with the aim to present a particular social issue present in Brazil, the spaces of life in the suburbs of the biggest Brazilian cities, from the content analysis and the ethical behavior of the group's Racionais Mc's. According to the authors, it seems favorable to understand how social groups in Latin American societies have reacted, even under challenging and restrictive circumstances, and have built mechanisms for social reaction.
\end{abstract}

Keywords Media; Periphery; Racionais Mc's; E thos; Solidarity.

\section{INTRODUÇÃO}

0 presente trabalho é proposto com 0 intuito de apresentar um particular cadinho social presente no Brasil, mas de suma importância para 0 entendimento de certos fenômenos socioculturais latino-americanos, junto a sua particular reação frente amodos devidaditados porparâmetros hegemônicos impostos por um amálgama mercadológico.

O grupo Racionais Mc's se constitui num expoente do fenômeno hip-hop brasileiro. Suas canções deixam claro o que se percebe em suas posturas deenfrentamento em face deumamecânica mercadológica. Surge como resultado da união de quatro jovens da periferia paulistana, que sendo recusados e recusando o mercado da indústria fonográfica, acabaram por se estabelecer como fenômeno de venda, como ídolos de uma geração de jovens pobres e como referenciais simbólicos identitários, a forjar "manos", em vez de jovens feios, pobres, pretos, quase pretos, e cabisbaixos.

A fim de demarcar os pressupostos, a saber: cenário conflituoso de ação cultural, tensões sociais e decodificações textuais, serão analisadas três letras que podem ilustrar os choques de convivência presentes no texto e no discurso dos Racionais Mc's: Fórmula Mágica da Paz (1997), Vida Loka 2 e Dá ponte pra cá (ambas de 2002).

O bservar-se-á, decerto, que o cotidiano dos costumes e hábitos perpassa e se coaduna a uma problemática que irá permear, inclusive, às contradições e inquietações do narrador no discurso dos Racionais Mc's, assim: 0 funcionamento comunicativo aos pares, aos "iguais", em confronto com os "diferentes", ou melhor, a operação de mediação no embate endógeno (espaço identitário) e enfrentamento exógeno (espaço do outro - os abastados no âmbito sócio-financeiro-cultural) determinaráum discurso inevitável forjado pela experiência que impulsiona um sujeito crítico.

A análise do conteúdo das letras virá acompanhada do processo investigativo proposto por Kellner (2001), de avaliação do fenômeno midiático a partir de três ambiências: (a) numa perspectiva da economia da comunicação, observando-se como se dá um tal movimento "insurgente", e quais são, por conseguinte seus mecanismosviabilizadores deapreço porumagrande massa de admiradores, (b) a análise do conteúdo já apontada, e finalmente (c) considerações acerca de como se dá a interpretação do público, frente aos mesmos, tanto aqueles que se identificam, quanto os que são implicados como sujeitos que afrontam aos "manos" (classe média e ricos). Nesse último momento, se observam considerações acerca dos mecanismos sistêmicos presentes nos ambientes sociais menos abastados, visando problematizar elementos de funcionamento de uma práxis-ação do sujeito identitário.

\section{Espaço social e caráter forjados pelo rompimento criativo}

Sodré (2002) não nos deixa esquecer que a escrita é um sistema que permite a reunião, acumulação de saberes e informações, mas que essa não nasceu da necessidade de acumulação informacional, mas como técnica de representar um vínculo entre pessoas. Por isso, assevera que o que de fato motiva a linguagem é a relação humana, e arremata exemplificando que a internet e os chats de relacionamento não são novos enquanto sistema, mas tão somente mais céleres operacionalmente.

Ao chamar atenção para as funções humanas que estão na base da formação da linguagem, inelutavelmente, traz luz para um 
espectro de necessidade que faz eclodir os desenvolvimentos de competências humanas, dentre as quais a destacar, a linguagem.

Autores como Gonzalez e Haselager (2002), ao pesquisar os elementos lógicos que fazem eclodir o desenvolvimento criativo no homem em sociedades, ou ainda dentro de espaços na natureza, inicia apontando que alguns autores identificam no processo dageração de novas ideias, o envolvimento de elementos irracionais.

Quando alguém pensa algo diferente, tem uma nova ideia, cria algo, e as motivações que levam tal sujeito a escolher estratégias para a resolução deproblemas não seresumem aelementos puramente suscetíveis de análise lógica, uma vez que dentre tais compostos encontram-se: elementos subjetivos, preferências e gostos (GONZALEZ; HASELAGER, 2002).

Autores como Peirce e Hanson, segundo Gonzáles e Haselager (2002), focam análise nos elementos racionais subjacentes a criatividade. Por isso, em seu texto encontra-se a seguinte passagem de um dos Collected papers de Peirce (1931-1958 apud GONZÁLES; HASELAGER, 2002, p. 24): "O pensamento criativo parece oscilar entre crenças bem estabelecidas e dúvidas ou surpresas que as abalam. [...] 0 processo de interrupção e abandono de uma crença não ocorre apenas por acaso, mas exige que alguma experiência se contraponha às expectativas."

Veja, disso se pode concluir que a interrupção de uma crença virá ocorrer apenas com o surgimento de uma nova experiência, sendo certo que neste sentido pode-se ter uma reação positiva que leva a uma atitude ativa como efeito mental ou então, pode-se ter uma reação negativa, que se circunscreve a um efeito mental passivo.

Tendo por foco o possível efeito mental ativo pode-seobservaraindaaseguintecontinuidade processual:um primeiro momento em queseobserva um efeito de surpresa, ou anomalia presente; posteriormente um estado em que a mente investiga este acontecimento surpreendente; finalmente, 0 instante em que ela pode encontrar uma hipótese explicativa que faz o organismo considerar corriqueira tal situação (a partir da junção de suas capacidades psíquicas somadas as referências racionais), ou então, o instante em que se pode perceber a ocorrência de um acordo entre as ideias na mente e aquelas relacionadas às leis da natureza que permitem aos homens, em constantestentativas, criar modos em que, por meio da insistência continuada, permita surgir ideias na mente do homem, relacionadas com as leis ou limites da natureza ou do meio, que se mantenham por uma lógica sistêmica de readaptação e mudança.

Dentro de uma perspectiva relacional humana, que não pode suprimir a vontade de domínio em relação ao outro e o risco do conflito, decerto constata-seque o homem veio adesenvolver, quando disposto num espaço hierarquicamente privilegiado, modos de redução da capacidade e fatores estimuladores de processos de explosão da criação do outro, vez que todos, inclusive seus "consortes", são irmanados, como vimos, com 0 sentimento de ruptura. Nota-se, por conseguinte um mecanismo claro que, vinculado às narrativas compartilhadas no espaço de mediação social, foi na história da humanidade ampliado de forma significativa pelos mídias, mecanismo que acaba por favorecer frente ao continuum da eclosão da descoberta, do rompimento, um modo de reduzi-lo à métrica de um modelo social vigente, tendo como efeito: a) evitar o espaço da descoberta para a maioria (muitas vezes inventando-a); b) propor sempre hipóteses determinadas, a fim de transparecer, à consciência que se firma e se amplia no contato coletivo, uma impressão de limites opcionais para determinado problema; c) propor teorias "lógicas", calcadas em narrativas que se fundam em elementos da experiência.

Por isso que num ambiente em que 0 espaço do conflito tendo mira a regulação da hierarquização e do domínio se sublima pela linguagem, signo e compreensão. E tendo esta última, vinculada à percepção dos processos em que o sujeito esteja implicado, é que então, de fato se poderá encontrar saídas espontâneas para a expressão da vida, ou da sobrevivência em determinados casos, em que se verá implicada, também, a nitidez consciencial com que se faz algo autonomamente, não serepetindo um modusoperandi, por um devir, por que as coisas são assim mesmo.

Morin (1975) ao tratar de questões relacionadas a como o homem por um processo revolucionário criativo rompeu com seu estado "bestial" e veio a constituir sociedade e linguagem, assevera que ainda que os elementos básicos fomentadores da constituição de um espaço organizado e hierarquizado que compõe a sociedade, não sejam propriamente dito humanos, posto que outros animais também os têm, contudo a 
possibilidadedesublimarumarelação queestácalcada numa necessidade presente e concreta, traduzida por fenômenos perceptíveis e de fácil compreensão empírica, e transformá-la no seu representamen, que com o passar do tempo faz os homens perderem contato direto com 0 objeto fomentador da experiência, que passa, por sua vez, a ser traduzida por um simulacro. Permite observar que, nesse contexto, são justamente os sujeitos subalternos, que não tendo acesso aos recursos mediadores de uma sociedade como esta, sendo obrigados a buscar alternativas no contato presente com as coisas e pessoas e suas respectivas nuances forjadas pela experiência do contato e do trabalho em si, que fazem eclodir espaços comunitários em que a compreensão identitáriadosprocessosdedominação, dos mecanismos de sobrevivência e da conformação social se estabelece, não isoladamente, mas de forma particular, por que não há outra alternativa, vez que, para estes o processo de marginalização é acentuado em diversos níveis estruturais.

Os Racionais Mc's apontam numa das canções selecionadas, "Fórmula mágica da paz", indícios deste processo, em que a identidade, 0 pertencimento espacial, cultural e social se dão sistemicamente imbricados:

Essa p* é um campo minado. Quantas vezes eu pensei em me jogar daqui, mas, aí, minha área é tudo que eu tenho. A minha vida é aqui e eu não consigo sair. É muito fácil fugir mas eu não vou. Não vou trair quem eu fui, quem eu sou. Eu gosto de onde eu vou e de onde eu vim, ensinamento da favela foi muito bom pra mim. Cada lugar um lugar, cada lugar uma lei, cada lei uma razão e eu sempre respeitei, em qualquer jurisdição, qualquer área [....]. (RACIONAIS MC'S, 1997).

A condição de marginalização do grupo social do qual faz parte os elementos do grupo Racionais Mc's já se define por marcas de clivagem social: a cor, as condições de escolaridade, 0 acesso aos bens culturais e de consumo, a marginalização de competências políticas junto às instituições públicas, o contato com a criminalidade como uma das saídas possíveis fomentadas pela cultura do meio e pela necessidade.

Fórmula Mágica da paz: "[...] Era só um moleque, só pensava em dançar, cabelo black e tênis all star. Na roda da função "mó zoeira!"
Tomando vinho seco em volta da fogueira. A noite inteira, só contando história, sobre 0 crime, sobre as treta na escola. Não tava nem aí, nem levava nada a sério. Admirava os ladrão e os malandro mais velho. Mas se liga, olhe ao seu redor e me diga: o que melhorou? Da função quem sobrou? sei lá, muito velório rolou de lá pra cá, qual a próxima mãe que vai chorar? [...]”. (RACIONAIS MC'S, 1997).

E ainda a violência e opressão dos meios "oficiais": polícia; Fórmula Mágica da paz: "[...] Eu já não sei distinguir quem tá errado, sei lá, minha ideologia enfraqueceu. Preto, Branco, Polícia, Ladrão ou eu, quem é mais filha da p*, eu não sei!" (RACIO NAISMC'S, 1997) edo prestígio, subordinação social edesvalorização de seus traços de cultura; D a Ponte Prá Cá: "[...] hã playboy bom é chinês, australiano, fala feio e mora longe, não me de mano [...]" (RACIONAIS MC'S, 2002).

Sujeitos a isso poderiam reagir dentro de diversas possibilidades para sobreviver física e psiquicamente, como se sugeriu anteriormente ao analisar-se os processos de ruptura criativa. No entanto, fizeram por um apreço pela transformação cultivada por um profundo senso de descontentamento que se afirmou e até hoje assim 0 fazem, sem permitir concessões, se quer, pela participação em momentos mediados pelos mídias em que pudessem dividir espaço com outros cujo comprometimento não fosse minimamente radical e vinculado a tais sintomas. Vida Loka 2: "[...] Nosso espírito é mortal, sangue do meu sangue, Entre o corte da espada e o perfume da rosa, sem menção honrosa, sem massagem. [...]" (RACIONAIS MC'S, 2002). Este é o caráter diferencial, caracterizador do grupo e que permite, justamente por isso, fazer deles reconhecidos e acolhidos, mesmo que distantes dos mecanismos de mediação mercadológica que apelam para formados do "homem médio", homem padrão eque detêm compromissos com estaredee com os modos e interesses de tal mercado.

Outrossim, justamente por esta condição possível (humanamente, e naturalmente como se viu) de reação, que os Racionais Mc's, pelo desempenho de radiografia de uma experiência partilhada por muitos, e pelo caráter de comprometimento consubstanciado também pela experiência, que tanto eticamente; Vida Loka 2: “[...] Enquanto zé povinho, apedrejava a cruz, um canalha fardado, cuspiu em Jesus, Hó..., A os 44 do segundo 
arrependido, salvo e perdoado, é Dimas o bandido.É loko o bagúio, arrepia na hora... D imas, primeiro vida lokadahistória." (RACIO NAISMC'S, 2002), quanto pelas potencialidades pragmáticas (e não puramente teóricas) de intervenção pela qual tal grupo acaba por se forjar em paradigma, mesmo para aqueles que os observam, ainda que irreflexivamente ou não, com repúdio e desdém, são refúgio para o inquietamento do insatisfeito, ou do sujeito atento para mazelas do sofrimento legitimado por símbolos, fatos e mecanismos de exclusão.

\section{Modelo ético de Racionais Mc's}

No dia 25 de setembro de 2007, o vocalista dos Racionais Mc's, Mano Brown, concedeu uma entrevista ao programa Roda-viva da Tv Cultura. Em tal entrevista surpreendeu mesmo àqueles que já conheciam seu trabalho ou nutriam por elealguma admiração, uma vez que em tal programa, Mano Brown apresentou um modelo ético muito particular e que se coaduna com as condições do processo de eclosão criativa, bem como com uma noção de confiabilidade entre sujeitos, formas de ação e compromissos que só se garantiriam, substancialmente, em razão de marcas cosidas por linhas e mãos nas relações próximas, tanto no que tange ao tempo e espaço, quanto à experiência psíquica mais sincera e vívida.

Em tal entrevista declarou que nos espaços de vida da periferia, os elementos de diferenciação, de clivagem, presentes no campo de convivência com a classe média ou rica: cor, condição de renda, profissão, etc, não eram sequer notados como traço identitário dos indivíduos. Na verdade, segundo Mano Brown, na periferia, todo mundo é preto e pobre, esua condição de marginalidade econômicosocial, faz a muitos se sentir assim, ou ser deste modo tratado.

Por tais razões, Mano Brown descreveu ao ser inquirido sobre os fatores de divisão moral tendo em vista os modulares parâmetros da classe média e a realidade das favelas, por que se permitia perceber positivamente os "bandidos", por exemplo, em suas canções. Brown, então explicou que no espaço de sobrevivência, "da ponte pra lá" da vida da classe média paulistana, para se reconhecer uma pessoa, ou um lugar, uma atitude e compreendê-la como suscetível de respeito, não se tinha como elemento primário um padrão moral dogmático, masjustamente a relação entre os indivíduos, próximos em função de relações de convivência como o elemento fundador do julgamento ético válido. Pois para ele, é valido inquirir: como saber se algo é bom ou não, como entender a dimensão humana de um sujeito (mesmo que cometa um ato ilícito), se não pela relação de convivência com o mesmo.

Por isso são tão importantes as relações de solidariedade, no exercício das funções sociais neste espaço.D iantedelas, a sociedade "formal", burguesa, é que não é honesta, e que é criminosa e omissa, posto queagridea todo momento aquele contingente humano marginalizado. D esde atos exteriorizados por agentes institucionais: o policial, o promotor, 0 juiz que pende sempre a condenar o pobre, quanto pelo ato de não cumprimentar o porteiro do prédio, ou a empregada em sua casa, ou de não inquiri-la, ao menos, acerca de como passou seu dia, tendo em vista que não os tem, de fato, em prática, como próximos, como iguais. Nesse ponto, Brown descortina 0 amargo por dentro da casca do sujeito festivo, cordial e tolerante brasileiro.

O caráter de sobrevivência fisiológica e psíquica tem como adversários a sociedade burguesa, segundo ele. A honestidade se prova na família, no meio entre amigos, no espaço de convivência aproximada. Por tal razão, por vezes o ladrão, 0 malandro é mais confiável que 0 homem de batina.

Quanto à ideia do romântico trabalhador que sofre na periferia violenta, destaca que se tem aí a figura do herói (lembremos do índio de nossa literatura romântica) que só apanha. Destaca, também, elemento crucial de nossa sociedade, já apontado por antigos sociólogos, inclusive pelo conservador O liveira Vianna (1974), que é o de que a lei não é feita para todos, mas, que funciona a beneficiar uns e a repreender outros, conforme podemos depreender da seguinte passagem: "Esta discordância entre o direito-lei e a realidade social (direito costume) é, com efeito, um traço dominante da história política dos povos latino-americanos. É um fato geral, que decorre do tradicional "marginalismo" das suas elites políticas." (OLIVEIRA VIANNA, 1974, p. 20).

Mano Brown também destacou que é justamente em razão desta relação dia após dia de contato direto com todos, inclusive com seus admiradores, de forma natural, e sem se portar como um difusor de verdades (o que se depreende também dos conteúdos de suas canções), é que foi permitido ao trabalho do grupo se tornar um 
fenômeno de venda, sem que deixassem de ser refutados, ao contrário, sobretudo no início da carreira, pelas grandes gravadoras e distribuidoras.

Kellner (2001) aponta este aspecto como importante na avaliação dos liames ideológicos de produtos midiáticos na lógica capitalista do mercado. Neste sentido a independência do grupo é algo que impressiona. Muitas vezes chegou a vender discos nos locais de shows, sem a mediação de distribuidores e nos últimos discos, conseguiu atuar com uma gravadoraindependentequecriaram. Assim, percebese na promoção do grupo uma ação isenta, e este é seu esforço constante (que raramente se apresenta em televisão ou concede entrevistas, sendo que quando o faz avalia o espaço e programa), a perseguir o distanciamento de liames com os responsáveis pelos grupos econômicos que tem ao seu redor outros liames com grupos políticos e econômicos apoiadores do mercado e por conseguintes conservadores. A viabilidade econômica do produto oferecido pelos Racionais Mc's está calcada no prestígio que detém nos espaços populares degrandes metrópoles e mesmo da classe média, que em alguns nichos percebe a profundidade e 0 caráter ideológico e a radiografia social do trabalho.

0 efeito de sentido oportunizado pelos conteúdos se insere dentro de uma lógica comportamental do receptor de tais mensagens, posto que, tais canções não sendo veiculadas de forma convencional, nos mídias e sendo difundidas, sobretudo, pela oralidade, acabam por exigir dos seus admiradores um contato mais intimista e de compreensão da postura e conteúdos do grupo, ao passo quedosseus antagonistas, quenão são poucos, obviamente, em regra, se descobre um desconhecimento acerca dos conteúdos e uma base generalizadora epreconceituosaqueo próprio grupo denuncia em suas músicas acerca dos "playboys", da classe média e rica (que os hostilizam e os tratam por "manos", ou ainda, que os tem não por "gente bonita" que se encontra em espaços aprazíveis da convivência burguesa da classe média e alta).

\section{0 espaço do cotidiano - a cotidianidade}

No turbilhão de referenciais presente nos textos dos Racionais Mc's, uma questão se mostra premente: 0 esforço na busca identitária grupal. Há uma propensão no encadeamento de ideias muito sólidas em relação à noção de "grupo" nas letras do grupo de rap paulistano. Nesse sentido, 0 processo de convívio permanente com um cenário "sujo", "hostil" e "violento" adquire facetas comportamentais pulsantes e corrosivas.

O ra, éclaro que, no bojo detal perspectiva, o cotidiano passa a representar um arcabouço de sutilezas e premissas urgentes.

Para demarcar os pressupostos, apontados no início do trabalho: cenário conflituoso de ação cultural, tensões sociais e decodificações textuais, as três letras selecionadas podem ilustrar os choques de convivência presentes no texto eno discurso dos Racionais Mc's, visto que elas insinuam representações reportivas ao cenário verificado, adquirindo ares de "crônica de costumes": F órmula Mácica da Paz (RACIO NAIS MC'S, 1997), V ida L ok a 2 eD á pontepra ć (RACIO NAIS MC'S, 2002).

E importante salientar que ocorre em tais textos a configuração de um processo "estranho" de resistência, no sentido de choque ininterrupto com agentes externose, até mesmo, internos do convívio social do narrador (o eu lírico das canções) em questão: no caso, um narrador envolto aos ditames de vida dos arredores da periferia da cidade de São Paulo, o bairro deCapão Redondo, especificamente. O u seja, delineia-se um fabrico de não concessão a vários códigos culturais estabelecidos. Mais do que propagar o advento de uma contracultura pautada e legitimada por marcas, 0 discurso e ação do narrador propõem e/ ou buscam marcas identitárias de ruptura e choque com o "outro": este "outro" representado ora por antagonistas periféricos (em críticas a posturas alienantes, morais e éticas), ora por antagonistas externos (o mundo da classe média e sua ostentação).

Em todo esse caminho de enfrentamento discursivo algumas oposições se mostram claras: conflitos endógenos x conflitos exógenos; sujeito periférico x sujeito classe média.

Eu queria ter, pra testa e vê, um malote, com glória, fama, embrulhado em pacote, se é isso que ceis qué, vem pegá; jogar num rio de merda e ver vários pulá, dinheiro é f*, na mão de favelado é mó guela, na crise, vários pedra 90, esfarela [...] imagina nóis de Audi, ou de Citroen, indo aqui, rindo ali, só pam, de vai e vem, no Capão, no apurá, vô colá, na Pedreira do São Bento, na fundão, no pião, Sexta-feira; de teto solar o luar representa, ouvindo Cassiano, os gambénão guenta. (RACIONAIS MC's, VIDA LOKA 2, 2002). 
O espaço a que os Racionais Mc's desenvolvem seu "manual de conduta" é fragmentário, difuso, heterogêneo. Entretanto, o fator de desigualdades (sociais, raciais e culturais) reforça o caráter poético das letras, na medida em que o espaço identitário diário é preenchido justamente pelos códigos inevitáveis do cotidiano: a tensão, a violência presente, as imagens midiáticas focalizadas pelos televisores nos barracos. Assim, 0 sujeito-narrador no discurso participa em um processo de mediação que não é meramente simplório, visto que o elemento anímico do contato diário está presente. A práxis cultural comunicativa (mass media, mensagens, efeitos, consumo) é projetada, exigida e, muitas vezes, fundamentada na configuração de um "novo" modelo/ paradigma de pauta do cotidiano: já que o convívio e o costume separam-se nos devaneios tortos de uma vida não sedimentada pelo modus operandi capitalista, resta ao narrador abrupto dos Racionais Mc's redefinir e/ ou subverter o jogo de consumo, de cultura e de relação entre emissor e receptor.

De acordo com Martin-Barbero (2001) 0 "lugar" redefine aspectos da interação emissor/ receptor na medida em que motores vivos e anímicos das relações cotidianas desempenham novas configurações quando se dá o choque entre agentes diferenciados, distintos. Nesse sentido, o "consumo" adquire status de regente comunicacional:

O espaço da reflexão sobre o consumo é 0 espaço das práticas cotidianas como lugar de interiorização mudadadesigualdade social, desde a relação com o próprio corpo até 0 uso do tempo, o hábitat e a consciência do possível para cadavida, do alcançável eo inatingível. Mas também como lugar da impugnação desses limites e expressão dos desejos, subversão de códigos e movimentos da pulsão e do gozo. (MARTIN-BARBERO, 2001, p. 302).

Nota-se, pois, que o cotidiano dos costumes e hábitos perpassa e se coaduna a uma problemática que irá permear, inclusive, as contradições e inquietações do narrador no discurso dos Racionais Mc's: o funcionamento comunicativo aos pares, aos "iguais", em confronto com os "diferentes", ou melhor, parafraseando, a operação de mediação no embate endógeno (espaço identitário) e enfrentamento exógeno (espaço do outro - os abastados sóciofinanceiro-culturais).

\section{Problemáticas do funcionamento da práxis-ação do sujeito identitário}

Thompson (1998) propõe análise das interações que surgem com 0 advento das transformações histórico-culturais pautada pelos arcabouços tecnológicos e midiáticos. É preciso ressaltar que o discurso e a descrição do ambiente periférico nos Racionais Mc's dialogam com tais avanços: daí, talvez, o surgimento do descompasso e da arritmia corrosiva dos enfrentamentos sociais. Mas isto se dá, evidentemente, por meio de interações. Segundo Thompson (1998), a interação fac a face acontece em um envolvimento de trocas simbólicas íntimas, participativas; sugestivas de uma práxis comunicativa mais "oralizada":

A interação face a face acontece num contexto de co-presença; os participantes estão imediatamentepresentesepartilham um mesmo sistema referencial de espaço e de tempo. Por isso eles podem usar expressões denotativas ("aqui", "agora", "este", "aquele", etc.) e presumir que são entendidos. As interações face a face tem também uma caráter dialógico, no sentido de que geralmente implicam ida e volta no fluxo de informação e comunicação; os receptores podem responder (pelo menos em princípio) aos produtores, e estes são também receptores de seus comentários. (THOMPSO N, 1998, p. 78).

D essa forma, a interação face a face adquire um papel fundamental na práxis-ação do texto, na medida em que, por meio do diálogo identitário, fortemente fincado no espectro da cotidianidade, configura-se a assimilação e apropriação discursiva de fatria, de comprometimento, de "irmandade" dos sujeitos acionais na obra dos Racionais. $\mathrm{Ou}$ seja, a denominação "mano" demarca um espaço de ação - muito específico - geográfico, social, cultural, em que as ações de identidade, de resistência, de luta, de solidariedade dialogam com a violência, racismo, privações, carências etc. Nesse sentido, os "manos" são protagonistas de uma história "coerentemente" contada, visto que, pela configuração de uma práxis identitária sui generis, o elo de identidade se constrói. Assim, a visceralidade que surge no discurso dos sujeitos periféricos (os "manos") serve parailustrar - como um produto cultural independente altamente corrosivo - quadros, formas, atitudes de um lado 
carcomido do cenário urbano; longe, pois, das discussões homogeneizantes do processo globalitário do capitalismo contemporâneo.

A localização e identificação de um novo cenário, com novos atores sociais é, portanto, a sina e a ação de choque social cujo andamento se verifica no centro do próprio funcionamento social da cidade de São Paulo em seu apartheid funcional. Vê-se um trecho de V ida L oka 2:

Ás vezes eu acho que todo preto como eu, só qué um terreno no mato, só seu; sem luxo, descalço, nadar num riacho, sem fome, pegando as fruta no cacho; aí truta, é o que eu acho, eu quero também, mas em São Paulo Deus é uma nota de 100! Vida loka! (RACIONAIS MC'S, VIDA LOKA 2, 2002).

Essa discussão descritiva dos códigos de conduta de vida dos "manos" da periferia, do universo tensivo-ético dos Racionais evidencia, como já foi colocado, um motor de fraternidade, de convívio, de entrega, de estreitamento entre 0 sujeito cultural e os objetos assistidos. Com isso, os "manos" desempenham e/ ou vaticinam um processo deinteração facea facemuito mais veemente. Kehl (2004) identifica o status colocado na convivência cultural nas letras dos Racionais Mc's:

O tratamento de "mano" não é gratuito. Indica uma intenção de igualdade, de sentimento de fatria, um campo deidentificações "horizontais", em contraposição ao modo de identificação/ dominação "vertical", da massa em relação ao líder ou ao ídolo. As letras [dos Racionais Mc's] são apelos dramáticos ao semelhante, ao irmão: junte-se a nós, aumente nossa força. Fique esperto, fique consciente. (KEHL, 2004, p. 17).

Com a fala de Kehl uma pergunta se faz necessária e urgente: como, no contexto de uma atuação "fechada" e/ ou pautada pelos "manos", ocorre o contato da obra dos Racionais Mc's com 0 ambiente externo (elites culturais, financeiras)? Como funciona a interface midiática nos textos dos Racionais Mc's (no discurso e na práxis) com valores embutidos de uma so ciedade midiatizada?

\section{Ethos e sociedade midiatizada}

D eacordo com Sodré(2002), na sociedade midiatizada surge um ethos que tem agregado a si valores condicionados a configurações de embate social, uma vez que o mito da igualdade solidária no processo dos avanços tecnológicos "falha" e deixa pistas de um desordenamento paradoxal. A partir detal desordenamento técnico acarreta-se 0 advento de uma moralidade midiática, na qual um discurso hegemônico midiático surge como expressão do ânimo autoconservador de um modelo social, que propõe sempre a necessidade de se adaptar e buscar acondição de sujeito inserido numalógica capitalista de fruição e detenção de força, de "competência". Restando ao sujeito resignado, no mundo "fora da tela" contemplar sua pequenez diante de sua impossibilidade de se fazer inserido em tal padrão de "cidadão do mundo".

A acomodação ou desconforto, frente a umasociedade estruturadapor práticas de prestígio, individualidade e direitos de compra, dependem de quanto o sujeito se percebe desafortunado, ou então submetido ao império de um modelo rígido de ações. O ra, o eu lírico de Fórmula M ágica da paz irá mostrar que novos modos de operação de vida se chocam com as condições de precariedade de um cenário cada vez mais "real" e, paradoxalmente, longe da narrativa midiática:

Hojetá da hora o esquema pra sair, é, vamo, não demora, mano, chega aí! 'cê viu onti? Os tiro ouvi de monte! Então, diz que tem uma pá de sangue no campão'. Ih, mano, toda mão é sempre a mesma idéia junto: treta, tiro, sangue, ái, muda de assunto. Traz a fita pra eu ouvir porque eu tô sem, principalmente aquela lá do Jorge Bem. Uma pá de mano preso chora a solidão. Uma pá de mano solto sem disposição. Empenhorando poraí rádio, tênis, calça, acende num cachimbo [...]viroufumaça!..(RACIO NAIS MC'S, FÓ RMULA MÁG ICA DA PAZ, 1997).

Nesse contexto, apropriando-se do ethos midiatizado elucidado por Sodré, tem-se, no texto dos Racionais, uma discussão tensiva entre aparatos do "real" edeum "utópico fantástico mundo novo". Não é de se estranhar que, com tal tensão, quadros de vida saltam aos olhos na obra dos Racionais Mc's. Eis alguns trechos em que ocorrem a demarcação e identificação de ethos, personalidades e valores no narrador das três canções: Fórmula Mágica da paz: "minha área é tudo o que eu tenho. A minha vida é aqui e não consigo sair" (RACIO NAIS MC'S, 1997); Vida Loka 2: "G raças a Deus a gente ta com saúde, morô, muita coletividade na quebrada" (RACIONAIS MC'S, 
2002). D a ponte pra cá: “Mesmo céu, mesmo cep, no lado sul do mapa, sempre ouvindo rap pra alegrá a rapa"(RACIO NAIS MC'S, 2002).

Sodré, evidentemente, dialoga com Thompson e Martin-Barbero quando retoma a questão do hábito e do costume cotidiano como vetor das transformações e conflitos (na maioria das vezes não pacíficos, sobretudo no contexto econômico-social latino-americano em que as condições materiais de vida partilhadas não permitem uma resignação e ponderação atitudinal, face ao imperativo da luta pela sobrevivência diária, tendo por comparação os países do norte) no debate social e cultural em contato com um "mundo informacional linkado em rede e carregado de simbologias":

Caráter e personalidade afirmam-se, portanto, no modo como o sujeito se conduz, age ou produz. Aí se instala a consciência “prática”, de onde parte 0 controle reflexivo sobre a ação dos agentes sociais, estaque, ao realizar-se, pode transformar tanto o sujeito quanto o objeto. A palavra "prática" [...] designa, desde Platão, além da ação imanente pela qual o sujeito, 0 indivíduo vivencia o padrão rotineiro do ethos, também a possibilidade de transformá-lo, em virtude da finalidade de um bem-agir ou um bem-fazer. (SOD RÉ, 2002, p. 47).

Não há dúvida de que, quando os Racionais Mc's propõem o enfrentamento com os abastados, está colocada a questão nevrálgica dos aspectos tensivos evidenciados por Sodré e categorizado, através das interações, por Thompson. Isto é, ocorre, consequentemente à oposição entre sujeito periférico esujeito "playboy", a dualidade entre um universo informacional globalizado e tecnificado com um mundo de precariedades. É óbvio que, com a sedimentação detal conflito, as práticas culturais são emolduradas por éticas distintas, não poucas vezes atreladas à práxis consumista, visto que o consumo desempenha, no dizer de Martin-Barbero, peçachave para o entendimento dos "fazeres culturais" na pulsação da vida contínua e diária.

Com estas ambiguidades, uma máxima conflitiva percorrerá toda obra dos Racionais Mc's: a violência versus aparatos culturais emancipadores (a questão da identidade autovalorativa, autoconsciente em um ambiente de trincheiras).

\section{CONSIDERAÇÕES FINAIS}

Em uma possível saída expansiva, colocase a necessidade de diferenciarmos os ingredientes éticos e valorativos da classe média e do sujeito periférico no cenário midiatizado contemporâneo. Aqui, é urgente localizarmos a diferença que para Milton Santos (2001) exercem os sujeitos, numa lógica estratificada, os papéis de atores sociais no cenário globalitário (os pobres e a classe média).

$\mathrm{Na}$ convivência com a necessidade e com 0 outro, se elabora uma política, a política dos de baixo, constituída a partir das suas visões do mundo e dos lugares. Trata-se de uma política denovo tipo, que nada tem aver com a política institucional [...] apolíticados pobresébaseada no cotidiano vivido por todos, pobres e não pobres, eéalimentadapelasimplesnecessidade de continuar existindo. Nos lugares, uma e outrase encontram e confundem, daía presença simultânea de comportamentos contraditórios [...] mas a semente do entendimento já está plantadae o passo seguinteéo seu florescimento em atitudes de inconformidade e, talvez, de rebeldia". (SANTOS, 2001, p. 132).

A certeza de não mais influir politicamente é fortalecida nas classes médias, levando-as, não raro, a reagir negativamente, isto é, a desejar menos política e menos participação, quando a reação correta poderia e deveria se exatamente a oposta. A atual experiência de escassez pode não conduzirimediatamenteàdesejável expansão da consciência. (SANTO S, 2001, p. 138).

Evidentemente que, por meio dessa dualidade escancarada, os Racionais tecerão exercícios de uma crônica de "costumes" dos cenários periféricos de São Paulo, pautados por uma postura de comprometimento, entrelaçamento, solidariedade (sujeito periférico) versus a ocupação dos agentes da classe média, dos chamados playboys pelos "manos".

No trecho seguinte de D a ponte pra cá, ocorre a síntese no diálogo não-pacifista entre tais atores:

Ce é cego doidão, então baixa o farol. Hei hou, se qué o que com quem Diow? Tá marcando, não dá pra ver quem é contra a luz, um pé de porco ou inimigo que vem de capuz. Hey truta eu to loco, eu to vendo miragem, um bradesco bem em frente da favela é viagem. D e classe A 
da Tam tomando Jb ou viajar de Blazer pro 92 $\mathrm{D}$ p. Viajar de G ti quebra a banca, só não pode viajar com os mão branca. Senhor guarda meus irmão nesse horizonte cinzento, nesse Capão Redondo frio sem sentimento. Os manos é sofrido e fuma um sem dar guela, é 0 estilo favela e o respeito por ela, os moleque tem instinto e ninguém amarela. Os coxinha cresce o zóio na função e gela. (RACIO NAIS MC'S, DA PONTE PRA CÁ, 2002).

Assim, o narrador nas três canções escolhidas, utilizando-se de um discurso documental, metalinguístico por vezes, com ares cinematográficos, irá verificar os códigos culturais dos desvalidos, "dos de baixo". Alguns blocos temáticos percorrerão as três canções na ânsia de emoldurar as fronteiras tensivas entre 0 sujeito periférico (o narrador), a descrição do microcosmo e os diálogos multirreferenciais com atores externos (o playboy, os policiais etc.): localização do cenário periférico, condição dos atores, mulher, formas de vida, violência, guerra x paz, actantes externos e "revisão de consciência".

\section{REFERÊ NCIAS}

GONZALEZ, M. E. Q.; HASELAGER, W. F. G. Raciocínio abdutivo, criatividade e autoorganização. Cognitio, n. 3, p. 22-31, 2002.

KEHL, M. R. Identidade e poder de inclusão. Carta Capital, ano 11, n. 310, p. 12-18, 29 set. 2004.

KELLNER, D ouglas. A cultura da mídia. São Paulo: EDUSC, 2001.

MARTIN-BARBERO, Jesus. Dos meios às mediações: comunicação, cultura e hegemonia. 2. ed. Tradução de Ronald Polito e Sérgio Alcides. Rio de Janeiro: UFRJ, 2001.

MO RIN, Edgar. 0 enigma do homem. Rio de Janeiro: Zahar, 1975.

OLIVEIRA VIANA, Francisco José. Instituições políticas brasileiras. Rio de Janeiro: Record, 1974. v. 2.
RACIO NAIS MC'S. (Interp.). Fórmula mágica da paz. São Paulo: Cosa Nostra, 1997. $1 \mathrm{CD}, 10^{\prime} 40.12$, digital, estéreo. Acompanha livreto.

Da ponte pra cá. São Paulo: Unimar music, 2002. 1 CD, 7, digital, estéreo. Aconpanha livreto.

Vida Loka 2. São Paulo: Unimar music, 2002. 1 CD, Added. 5:50, digital, estéreo. Aconpanha livreto.

SANTOS, Milton. Por uma outra globalização: do pensamento único à consciência universal. 6 . ed. São Paulo: Record, 2001.

SO D RÉ, Muniz. Antropológica do espelho: uma teoria da comunicação linear e em rede. Petrópolis, RJ: Vozes, 2002.

THOMPSON, John B. A mídia e a modernidade: uma teoria social da mídia. Tradução de Wagner de Oliveira Brandão. Petrópolis, RJ: Vozes, 1998.

Recebido: 07/ 10/2008

Received: 10/ 07/ 2008

Aprovado: 28/ 10/ 2008

A pproved: $10 / 28 / 2008$ 